\title{
ANALISIS RESIKO PETUGAS KEBERSIHAN YANG MENANGANI LIMBAH MEDIS DI RUMAH SAKIT UMUM HAJI SURABAYA
}

M. Idris Rizaldi, AT Diana Nerawati, Setiawan

Jurusan Kesehatan Lingkungan Poltekkes Kemenkes Surabaya

Email : idris.rizaldi1997@gmail.com

\begin{abstract}
ABSTRAK
Hasil survei pendahuluan yang dilakukan di Rumah Sakit Umum Haji Surabaya, menunjukkan bahwapengeloaan limbah medis di rumah sakit haji dikelola oleh petugas kebersihan yang kemudian dibuang ke tempat sampah medis dan di musnahkan oleh pihak ketiga atau outsoursing yang bekerja sama dengan Rumah Sakit Umum Haji Surabaya.

Resiko kerja yang dialami oleh petugas kebersihan merupakan masalah kesehatan dan keselamatan kerja di rumah sakit yang perlu mendapat perhatian. Sumber bahaya yang ada di rumah sakit harus di analisis untuk menentukan tingkat resiko yang merupakan tolak ukur untuk kemungkinan terjadinya kecelakaan akibat kerja dan penyakit akibat kerja pada petugas kebersihan. Tujuan penelitian ini Mengelola resiko harus dilakukan secara berurutan langkahlangkahnya yang bertujuan untuk membantu dalam pengambilan keputusan yang lebih baik dan melihat resiko dan dampak yang kemungkinan ditimbulkan.

Penelitian dilakukan secara deskriptif, Teknik pengambilan sampel

yang digunakan dengan cara Proportionalrandom sampling, yang dalam hal ini jumlah unit dari tiap strata dan sampel juga tidak sama, yaitu sebanding pada 48 petugas kebersihan, yang diambil berdasarkan dari shift kerja pada RSU Haji Surabaya.

Analisis resiko pada petugas kebersihan terhadap penanganan limbah medis padat di RSU Haji Surabaya yaitu dalam proses kegiatan pemilahan,pewadahan, pengangkutan di dapatkan resiko "Rendah" dan "sedang", sedangkan pada kegiatan proses penyimpanan di dapatkan kategori "Tinggi" dan "Sangat Tinggi".
\end{abstract}

\section{Kata Kunci : : Limbah Medis, Petugas Kebersihan}

\section{PENDAHULUAN}

Undang-undang Republik Indonesia no.44 th 2009 tentang rumah sakit menjelaskan bahwa Rumah Sakit adalah institusi pelayanan kesehatan yang menyelenggarakan pelayanan kesehatan perorangan secara paripurna yang menyediakan pelayanan rawat inap, rawat jalan, dan gawat darurat.

Penyelenggaraan pelayanan kesehatan di Rumah Sakit mempunyai karakteristik dan organisasi yang sangat kompleks. Berbagai jenis tenaga kesehatan dengan perangkat keilmuannya masing-masing berinteraksi satu sama lain. dalam rangka pemberian pelayanan yang bermutu, membuat semakin kompleksnya permasalahan dalam Rumah Sakit.

Keputusan Menteri Kesehatan Republik Indonesia Nomor 1204 Tahun 2004 menjelaskan bahwa Rumah sakit sebagai sarana pelayanan tempat berkumpulnya orang sakit maupun orang sehat, atau dapat menjadi tempat penularan penyakit serta memungkinkan terjadinya pencemaran lingkungan dan gangguan kesehatan. Untuk menghindari resiko dan gangguan keesehatan, maka perlu penyelenggaraan kesehatan lingkungan rumah sakit meliputi: Penyehatan ruang bangunan dan halaman rumah sakit, Persyaratan higiene dan sanitasi makanan minuman, Penyehatan air, Pengelolaan limbah, Pengeloaan tempat pencucian linen (Laundry), Pengendalian serangga, tikus dan binatang pengganggu lainnya, Dekontaminasi melalui desinfeksi dan sterilisasi, Persyaratan pengamanan radiasi, Upaya promosi kesehatan dari aspek kesehatan lingkungan.

\begin{tabular}{lcrr}
\multicolumn{2}{c}{ Pengelolaan limbah rumah sakit } \\
dilakukan harus & sesuai & dengan \\
persyaratan yang & mengacu pada
\end{tabular} Peraturan Menteri Kesehatan 1204 tahun 2004. Limbah rumah sakit adalah semua limbah yang dihasilkan dari kegiatan rumah sakit dalam bentuk padat, cair dan gas. Limbah padat rumah sakit menjadi limbah medis padat dan limbah non medis. Keberadaan sebuah rumah sakit dengan produksi limbah yang bersifat medis dan infeksius memberikan kontribusi dalam penyebaran penyakit, tidak hanya di dalam rumah sakit tetapi di 
lingkungan rumah sakit.

Rumah sakit dan instalasi kesehatan memiliki kewajiban untuk memelihara lingkungan dan kesehatan masyarakat, serta memiliki tanggung jawab khusus yang berkaitan dengan limbah yang dihasilkan instalasi tersebut. Kewajiban yang dipikul instalasi tersebut di antaranya adalah kewajiban untuk memastikan bahwa penanganan, pengelolaan serta penyimpanan limbah yang mereka lakukan tidak akan menimbulkan dampak yang merugikan kesehatan dan lingkungan. (pruss, 2005)

Salah satu upaya yang dilakukan rumah sakit dalam rangka penyehatan lingkungan yakni menyelenggarakan pelayanan sanitasi rumah sakit, yakni pengelolaan limbah. Pengelolaan limbah merupakan salah satu aspek strategis dari rumah sakit, karena dengan pengelolaan limbah yang baik akan menciptakan citra yang baik dari rumah sakit.

Tenaga non medis di rumah sakit diantaranya adalah petugas kebersihan. Tenaga kebersihan adalah karyawan yang bertugas membersihkan lingkungan rumah sakit agar tetap terjaga kebersihannya. Pekerjaan membersihkan lingkungan rumah sakit, membuat petugas kebersihan menjadi rentan terpapar bahaya yang dapat mengganggu kesehatannya. Menurut penelitian yang telah dilakukan bahaya dapat mengancam petugas

kebersihan rumah sakit antara lain terpapar debu yang telah dibersihkan, terpleset saat mengepel lantai, kontak dengan bahan kimia dan tertusuk benda tajam seperti jarum suntik saat mengelola limbah tajam, sehingga dapat tertular penyakit seperti hepatitis dan HIV/AIDS.

Hasil survei pendahuluan yang dilakukan di Rumah Sakit Umum Haji Surabaya, menunjukkan bahwa rumah sakit menghasilkan limbah padat yang dibedakan menjadi dua jenis yaitu limbah medis dan limbah non medis dengan besar limbah medis yang dihasilkan sebanyak $4918 \mathrm{~kg} /$ bulan sedangkan limbah non medis sebanyak $9178 \mathrm{~kg} / \mathrm{bulan}$ pada bulan desember 2018. Pengeloaan limbah medis di rumah sakit haji dikelola oleh petugas kebersihan yang kemudian dibuang ke tempat sampah medis dan di musnahkan oleh pihak ketiga atau outsoursing yang bekerja sama dengan Rumah Sakit Umum Haji Surabaya.

Diketahui pula menunjukkan sebagian petugas kebersihan dalam melakukan penanganan limbah padat tidak menggunakan Alat Pelindung Diri (APD) seperti sarung tangan, masker dan sepatu yang dapat menimbulkan resiko kecelakaan pada petugas kebersihan. Hal tersebut terbukti dari hasil wawancara dengan petugas kebersihanbahwa pernah terjadi kecelakaan (tertusuk) terhadap petugas kebersihan. Diketahui juga bahwa hal ini dapat meningkatkan resiko terjadinya kecelakaan kerja terhadap petugas kebersihan.

Resiko kerja yang dialami oleh petugas kebersihan merupakan masalah kesehatan dan keselamatan kerja di rumah sakit yang perlu mendapat perhatian. Sumber bahaya yang ada di rumah sakit harus di analisis untuk menentukan tingkat resiko yang merupakan tolak ukur untuk kemungkinan terjadinya kecelakaan akibat kerja dan penyakit akibat kerja pada petugas kebersihan.

Penyimpanan limbah masih dilakukan lebih dari 24 jam, menyebabkan terjadinya penumpukan sampah pada kontainer. Hal ini dapat meningkatkan resiko terjadinya kecelakaan dari segi estetika maupun penularan penyakit terutama pada petugas kebersihan. Dalam proses pemusnahan limbah medis padat rumah sakit bekerja sama dengan pihak ketiga karena insinerator yang dimiliki tidak memiliki izin sehingga tidak dapat dioperasionalkan.

Kesehatan dan keselamatan Kerja bertujuan melindungi pekerja atas keselamatannya agar dapat meningkatkan produktifitas nasional. Menjamin semua pekerja yang berada di tempat kerja menggunakan serta merawat sumber produksi secara aman dan efisien (Menkes, 2009).

Hasil laporan Nasional Safety Council (NSC) tahun 1988 menunjukkan bahwa terjadinya kecelakaan di Rumah Sakit $41 \%$ lebih besar dari pekerja di industri lain. Kasus yang sering terjadi di antaranya tertusuk benda tajam, terkilir, tergores atau terpotong, luka bakar, penyakit infeksi dan lain-lain (Kemenkes, 2007).

\section{Risk Management Standart} AS/NZS 4360;2004menyatakan bahwa analisis resiko bersifat pencegahan terhadap terjadinya kerugian maupun accident. Mengelola resiko harus dilakukan secara berurutan langkahlangkahnya yang bertujuan untuk membantu dalam pengambilan 
keputusan yang lebih baik dan melihat resiko dan dampak yang kemungkinan ditimbulkan.

\section{METODE PENELITIAN}

Penelitian ini dilakukan secara deskriptif. Lokasi penelitian dilakukan di RSU Haji Surabaya yang dilakukan pada bulan Desember 2018-Mei 2019. Populasi dalam penelitian ini adalah petugas kebersihan di RSU Haji Surabaya sebanyak 90 orang.

Teknik pengambilan sampel yang digunakan dengan cara Proportionalrandom sampling, yang dalam hal ini jumlah unit dari tiap strata dan sampel juga tidak sama, yaitu sebanding.

Dari perhitungan sampel ditemukan besar sampel yang diperbolehkan adalah 48 petugas kebersihan, yang diambil berdasarkan dari shift kerja pada RSU Haji Surabaya. Data diperoleh dari hasil observasi, wawancara, dan data penunjang.

\section{HASIL DAN PEMBAHASAN}

Proses pengelolaan limbah di Rumah Sakit Umum Haji Surabaya telah dilengkapi dengan Standart Operational Procedure (SOP) dan Alat Pelindung Diri (APD) yang dibutuhkaan. APD yang disediakan oleh RSU HAJI berupa disposable gloves, masker, baju lengan panjang, apron dan sepatu boots sedangkan menurut Djohan dan Halim (2014), APD yang diperlukan dalam pengelolaan limbah padat medis diantaranya masker, coverall (pakaian panjang), pelindung kaki atau safety boots, sarungtangankhusus (disposable gloves atau duty gloves), apron, pelindung mata dan topi atau helm. Dari proses tersebut memiliki beragam bahaya yang untuk diidentifikasi dan diketahui.

\section{A. Identifikasi resiko pada petugas kebersihan terhadap penanganan limbah medis padat di Rumah Sakit Umum Haji Surabaya}

Proses pengangkutan limbah dilakukan dalam 2 tahap, tahap yang pertama adalah pengangkutan limbah dari tiap ruangan ke gerobak sampah besar menggunakan troli. Tahap kedua dalam proses pengangkutan limbah padat medis adalah pengangkutan dari bangunan utama ke TPS di halaman belakang rumah sakit menggunakan gerobak sampah besar.

Setelah sampai di TPS, dilakukan pembongkaran isi dari gerobak sampah, penimbangan limbah dan penataan limbah padat medis dalam TPS. Pada tahapan tersebut petugas bekerja dengan postur yang tidak normal. Berdasarkan penilaian postur kerja yang dilakukan dengan metode REBA ditemukan empat postur kerja yang tidak normal yaitu mengangkat beban berat saat mengeluarkan limbah padat medis dari gerobak sampah, menimbang sampah menggunakan timbangan gantung, dan memindahkan kantong plastik limbah padat ke TPS dan menata kantong plastik dan safety box di TPS dilakukan secara berulang sesuai dengan jumlah limbah padat medis yang terkumpul. Bahaya lain yang ditimbulkan berasal dari jarum dari safety box yang memberikan risiko ganda yaitu cedera dan penularan penyakit (Pruss, et.al, 2005) hal tersebut dikarenakan terkadang safety box yang diangkut menggunakan gerobak sampah rusak dikarenakan tertimpa limbah padat medis lain di atasnya. Hasil identifikasi bahaya dilakukan dengan menggunakan data primer hasil observasi dan wawancara kepada petugas TPS dan petugas kebersihan karena proses pemusnahan limbah padat medis dilakukan oleh pihak ketiga.

B. Analisis resiko pada petugas kebersihan terhadap penanganan limbah medis padat di Rumah Sakit Umum Haji Surabaya

\begin{tabular}{lrr} 
Hasil & \multicolumn{1}{c}{ penilaian } & risiko \\
didapatkan & dari data & prime \\
berdasarkan & observasi & dan
\end{tabular} wawancara kepada petugas pengelolaan limbah padat medis. Penilaian risiko dilakukan untuk menentukan besarnya suatu risiko dengan mempertimbangkan faktor kemungkinan dan dampak yang ditimbulkan sehingga dapat dilakukan pemilahan risiko yang memiliki dampak besar dan risiko ringan yang dapat diterima (Ramli,2011).

Padaproses pengumpulan limbah padat medis padat tersebut terdapat beberapa bahaya. Bahaya pertama adalah tertusuk jarum suntik sisa pelayanan yang memiliki dua risiko yaitu cedera tertusuk dan tertular penyakit infeksi seperti HIV, hepatitis dan tifus akibat tertusuk jarum. Terdapat 4 kategori resiko pada analisis resiko, yaitu kategori 
rendah, sedang, tinggi, dan sangat tinggi. Pada penelitian yang dilaksanakan tentang analisis resiko petugas kebersihan yang menangani limbah medis padat di RSU Haji Surabaya didapatkan hasil bahwa kategori rendah ada 3 bahaya potensi pada proses kegiatan pemilahan, pewadahan,

dan penyimpanan. Untuk resiko rendah dan sedang hanya perlu dilakukan pemantauan rutin yang dilakukan oleh penanggung jawab. Pada kategori resiko tinggi terdapat pada proses kegiatan penyimpanan dengan bahaya resiko terpapar debu/polutan ruangan, terkena cairan kimia. Untuk resiko sangat tinggi terdapat pada proses kegiatan penyimpanan dengan bahaya resiko virus pada limbah medis dan vektor.

\section{Melakukan evaluasi resiko pada petugas kebersihan terhadap penanganan limbah medis padat di Rumah Sakit Umum Haji Surabaya}

Untuk evaluasi resiko pada petugas kebersihan terhadap penanganan limbah medis padat di Rumah Sakit Umum Haji Surabaya hanya dilakukan pada kategori resiko tinggi dan sangat tinggi karena hal tersebut dapat menimbulkan masalah yang dapat membahayakan petugas kebersihan.

\section{Penanganan resiko petugas kebersihan terhadap penanganan limbah medis padat di Rumah Sakit Umum Haji Surabaya}

Penanganan yang sudah dilakukan untuk mencegah dan mengendalikan resiko adalah dengan menggunakan APD (Alat Pelindung Diri). Penanganan resiko selanjutnya yaitu melakukan dan menetapkan SOP (Standart Operasional Prosedur). SOP bertujuan untuk menyelesaikan suatu pekerjaan yang bertujuan untuk memperoleh hasil kerja yang paling efektif dari para pekerja dengan biaya yang se rendah-rendahnya. Penanganan resiko secara teknis yaitu dengan memisahkan bahaya dengan pekerja serta untuk mencegah terjadinya kesalahan manusia seperti selalu menutup tempat sampah untuk mencegah penularan virus dan bakteri kepada petugas kebersihan seperti DBD, HIV Aids, Hepatitis, Iriasi kulit dan Diare.

\section{KESIMPULAN}

Berdasarkan hasil penelitian tentang Analisis resiko petugas kebersihan yang menangani limbah medis padat di RSU Haji Surabaya, maka didapatkan kesimpulan sebagai berikut:

1 Identifikasi resiko pada petugas kebersihan terhadap penanganan limbah limbah medis padat di RSU Haji Surabaya melalui tahap Pemilahan yaitu tertusuk jarum suntik, peralatan infuse dan benda tajam lainnya. Pada tahap Pewadahan identifikasi resikonya yaitu terkontaminasi cairan limbah medis infeksius. Pada tahap pengangkutan identifi resikonya yaitu terpleset dan terjatuh karena lantai licin dan tidak rata. Pada tahap penyimpanan identifikasi resikonya yaitu kontaminasi dari limbah medis yang mengandung patogen, bakteri, virus dan jamur.

2 Analisis risiko pada petugas kebersihan terhadap penanganan limbah medis padat di RSU Haji Surabaya yaitu dalam proses kegiatan pemilahan, pewadahan, pengangkutan di dapatkan resiko "Rendah" dan "sedang", sedangkan pada kegiatan proses penyimpanan di dapatkan kategori "Tinggi" dan "Sangat Tinggi".

3. Evaluasi resiko pada petugas kebersihan terhadap penanganan limbah medis padat di RSU Haji Surabaya yaitu dari bahaya potensi kimia dan biologi pada kegiatan proses penyimpanan yaitu kategori resiko "Tinggi" dan "Sangat Tinggi"dan pada kategori tinggi dan sangat tinggi harus mendapatkan perhatian khsusus

dikarenakan berdampak besar seperti tertular virus, bakteri dan bahan kimia lainnya sehinnga harus di tindak lanjuti dan mendapat perhatian dari pimpinan Rumah Sakit.

4. Penanganan risiko petugas limbah medis padat di RSU Haji Surabaya yaitu dengan eliminasi seperti menghilangkan tempat perindukan vektor dan binatang pengganggu, substitusi seperti memperbaiki lantai yang licin dan tidak rata, teknis seperti menutup tempat sampah dan kontainer sampah, administrasi seperti mematuhi SOP (Standart Operasional Prosedur) dan APD (Alat Pelindung Diri) seperti masker, 
sarung tangan dan sepatu boot.

\section{SARAN}

\section{Bagi Rumah Sakit Umum Surabaya}

a. Melakukan monitoring dan evaluasi mengenai keberadaan vektor dan binatang pengganggu yang ada di rumah sakit.

b. Menutup kembali tempat sampah yang masih dibiarkan dalam keadaan terbuka untuk mencegah timbulnya bbau yang tidak enak dan penularan vektor penyakit.

c. Perbaikan sarana prasarana dalam pengelolaan limbah padat medis diantaranya perbakan gerobak sampah besar atau kontainer dan jalur transportasi limbah padat medis yang dilalui sehingga limbah padat medis tidak tumpah dan tercecer.

2. Bagi Petugas Kebersihan

Melakukan pekerjaan sesuai dengan SOP (Standart Operasional Prosedur) dan selalu menggunakan APD lengkap dan mempertahankan kepatuhan dalam menggunakan APD (Alat Pelindung Diri)

3. Bagi Peneliti Lain

Untuk melakukan penelitian terhadap petugas kebersihan yang menangani limbah medis dan B3 di RSU Haji Surabaya

\section{DAFTAR PUSTAKA}

Asmadi., 2012. Pengolahan Limbah Medis Rumah Sakit. Yogyakarta: Gosyen Publishing.

Astuti, Agustina., dan Purnama S.G., 2014, Kajian Pengelolaan Limbah Di Rumah Sakit Umum Provinsi NusaTenggara Barat (NTB), Vol, 2 No. 1, hal 15, diakses 30 Desember 2017.

Bapelkes.2009. Modul Diklat ARKL. Bekasi: Bapelkes Lemahabang

Djohan, A.J dan Halim, Devy., 2013. Pengolahan Limbah Rumah Sakit. Jakarta, Salemba Medika.

Djohan, A. J., Devi H. 2014. Pengelolaan Limbah Rumah Sakit. Jakarta: Salemba Medika.

Fahriyah, Lailatul., Husaini, dan Fadillah Noor Ahda., 2016. Pengetahuan Dan Sikap Perilaku Perawat Dalam Pemilahan Dan Pewadahan Limbah Medis Padat. Publikasi Kesehatan Masyarakat, (Vol.3 No.3): 98

Farich,Achmad., 2012. Manajemen Pelayanan Kesehatan Masyarakat. Yogyakarta, Gosyen Publishing. Cetakan Pertama.
Haidah, N dan Irmawartini. 2018. Metodologi Penelitian. Surabaya : Hakli Prov Jatim.

Kementerian Kesehatan Republik Indonesia., Nomor 1204 tahun 2004 Tentang Persyaratan Kesehatan Lingkungan Rumah Sakit.

Line, $\operatorname{Rr}$ Domy dan Sulistyorini, Lilis., 2013. Evaluasi Sistem

Pengelolaan Sampah Di Rumah Sakit Umum Daerah Blambangan Banyuangi. Jurnal Kesehatan Lingkungan, (Vol 7, No 1): 71 72.

Maharani, Annisa Fitri, Afriadi, Irvan, dan Nurhayati, Titing., 2017.

Pengetahuan dan Sikap Tenaga Kesehatan Terhadap Pengelolaan Limbah Medis Padat Pada Salah Satu Rumah Sakit Di Kota Bandung.JSK, (Volume 3 Nomor 2): 88-89.

Maryani, Lidya dan Mauliani, Rizki., 2010. Epidemiologi Kesehatan. Yogyakarta, Graha IImu, Cetakan Pertama.

Meilani, Yuni, dan Hidayanti, Lilik, dan Novianti, Siti. 2014. Hubungan Pengetahuan Dan Sikap Petugas Terhadap Praktik Pengelolaan Sampah Medis Di Rumah Sakit Umum Daerah Ciamis.

Notoatmodjo, Soekidjo., 2011. Kesehatan Masyarakat. Jakarta, Rineka Cipta. Cetakan Kedua Revisi.2012. Promosi Kesehatan dan Perilaku Kesehatan. Jakarta, Rineka Cipta 2014.

Peraturan Menteri Kesehatan Republik Indonesia Nomor 56 Tahun 2014 Tentang Klasifikasi Dan Perizinan Rumah Sakit.

Peraturan Pemerintah Republik Indonesia Nomor 101 Tahun 2014 tentang Pengelolaan Limbah Bahan Berbahaya dan Beracun (B3).

Tualeka,A.R. 2015. Risk Assessment, Risk Management and Risk Communication Di Lingkungan Kerja. Penerbit: Bumi Lestari.

Undang-undang Republik Indonesia., Nomor 44 tahun 2009 Tentang Pengertian RumahSakit

Undang-Undang RI Nomor 44 Tahun 2009 tentang Rumah Sakit 
GEMA Lingkungan Kesehatan

VOL 18 NO 2 JULI 2020 